\title{
Linguistic Politeness and Greeting Rituals in German-speaking Switzerland
}

Felicity Rash (Queen Mary, London)

\begin{abstract}
This paper describes the results of research into linguistic politeness in German-speaking Switzerland (GSS) and into one type of politeness in particular, namely the speech acts of greeting and leave-taking denoted by the German verb grüssen. ${ }^{1}$ German-speaking Swiss people adhere to strict conventions of polite behaviour which have been eroded over time in the English-speaking world. My research shows that speakers of Swiss German, both young and old, and from all walks of life, believe that it is important to retain their traditional politeness rituals, and that greetings formulae are especially important. Very few germanophone Swiss that people conform to polite greeting practices out of self-interest (as one of my informants suggested), rather they believe that politeness is important for social cohesion and a sign of respect and affection for one's fellow human beings.
\end{abstract}

Im chliine Schwiizerland

vom Rhi- zum Rhoneschtrand

do seit me fründli "Sali, Sali"

me ghört's zu jeder Schtond

grad wome ane chunnt

ond got me ins Tessin

ins Land der Filafil

o mia bella Svizzera

de Ticinese kennt das

chliine Wörtli au

är seit "Saluti, Saluti, Ciao, Ciao".

(Song provided by Esther Baldenweg, Ennetbaden, AG)

\footnotetext{
${ }^{1}$ In German, the verb grüssen is used to refer to the actions of greeting and taking leave, the entries into and exits out of a social interaction. In this paper I will generally use the term "greeting" in this sense. For a number of my questions, however, it was necessary to differentiate between initial greetings and leave-takings: in these cases I have used grüssen to refer to the initial formulae only and sich verabschieden solely for terminal formulae (for example in 2.1.i.-vii).
} 


\section{A survey into linguistic politeness in Switzerland: background and methodology}

During the summer of 2002, I questioned 80 German-speaking (GS) Swiss people of a variety of ages and educational backgrounds about their views on current greeting practices and rules of politeness. At the outset I did not know how many willing informants I would find, so I decided upon a qualitative rather than a quantitative survey. I asked open questions in the hope of collecting a wide range of information and I was not disappointed. My informants were very happy to talk about all aspects of politeness and I learnt something new from each person that I interviewed. I was able to establish that a high proportion of everyday acts of politeness in GSS have a verbal aspect, greeting rituals being a prime example of this.

\subsection{What is politeness?}

Politeness is one of the most important aspects of human communication: human beings can only exist in peace together if certain basic conventions of politeness are observed. Since Penelope Brown and Stephen Levinson first developed a theory of linguistic politeness, most sociolinguistic studies have looked at politeness in terms of "face" (Hartung 2001: 214). Social cohesion depends upon awareness and consideration of the "face needs" of others. Each participant in normal human society has two types of face need: a "positive face need" and a "negative face need". The positive face need is 'the positive consistent self-image or "personality" (crucially including the desire that this self-image be appreciated and approved of) claimed by interactants' and the negative face need is 'the basic claim to territories, personal preserves, rights to non-distraction - i.e. to freedom of action and freedom from imposition' (Brown and Levinson 1987: 61). ${ }^{2}$ "Positive politeness" attends to a person's positive face needs and includes such speech acts as compliments, invitations and greetings. It expresses good-will and solidarity. "Negative politeness" attends to a person's negative face needs and includes indirectness and apologies. It expresses respect and consideration (Holmes 1995: 154).

It is normal for interactants in a communicative act to respect the face needs of others. Failure to do so is seen as an intrusion into another's personal space, or "territory"; as a "face threatening act" (FTA) (Lüger 2001: 6). FTAs include threats, insults, criticism and orders. The negative effect of an FTA may be reduced or totally eliminated by a variety of types of corrective "face work". Such "face-redressive" or "face-saving" work may involve linguistic indirectness, such as modal verbs, particles or hedges, as in: 'Möchten Sie nicht etwa das Fenster schliessen?' [Wouldn't you like to close the window?]. An FTA may also be mitigated by an apology, as in: 'Es tut mir leid, wenn ich Sie störe, aber würden Sie das Fenster bitte schliessen?' [I'm sorry to bother you, but would you please close the window?]

Following Brown and Levinson, Françoise Hammer identifies a "cost-benefit-scale" ("Kosten-Nutzen-Rechnung") as a factor of politeness in human interaction (Hammer 2001: 130). Politeness may be seen as an exchange of goods ("Warenaustausch") in which there is

\footnotetext{
2 Brown and Levinson's theory of face derives ultimately from Durkheim, The Elementary Forms of Religious Life (1915); see also Holmes 1995: 5f.
} 
frequently an unequal power-relationship between the giver and the receiver. Politeness thus contributes to the profit-maximization (Hammer's "Profitmaximierung") of an interaction; it is a means to an end (see Brown and Levinson 1987: 65, who use the term "minimum cost assessment" to refer to the rational need of human beings 'not to waste time to no avail'). For Janet Holmes, negative politeness tends to be associated with power and (social) distance; positive politeness with solidarity and friendliness. Holmes's thesis is that women, having less power, are more positively polite than men (Holmes 1995: 7f.). In the course of my research I asked my 80 informants why they thought it important to greet and only two people (one man and one woman) gave 'Nützlichkeit' (self-interest) as an answer, both giving the example of neighbours, particulary in rural areas, who always greet one another politely in case they ever need to ask for help.

Politeness, particularly positive politeness, is to a large extent dependent on ritual which is defined by Brown and Levinson as 'repetitive or pre-patterned behaviour' (1990: 43). They agree with Durkheim that interpersonal rituals are primordial, and that they sustain the sacred nature of the human personality: 'The human personality is a sacred thing: one dare not violate it nor infringe its bounds, while at the same time the greatest good is in communion with others' (Durkheim 1915: 73, quoted from Brown and Levinson: 44). Current European politeness conventions and rituals are said to have developed during the Middle Ages as 'ranggebundene(n) Herrschaftszeremonielle' [status-dependent rituals] (Kleinberger Günther 2001: 148) (See also Kleinberger Günther: 148 on politeness rituals as signals of respect ("Respektbezeugungen") and subordination ("Unterwerfungsgesten") of people with less power.) During the course of my survey, one informant suggested that greeting rituals stem from a time in prehistory when the arrival of any stranger could spell danger: verbal and gestural signs would have been important to show that people meeting for the first time intended no threat to one another. This accords with Iwar Werlen's interpretation of the ritual elements of greeting, especially opening rituals, as gestures of peace (Werlen 1992: 146).

While the consideration of face needs tends to be seen as a universal element of all social systems, the conventions and rituals surrounding politeness vary between cultures and will also depend on such factors as the relationship between the interactants and the social situation (Held 2001: 117). Gudrun Held writes of the importance of social upbringing ('soziale Erziehung') and subjective interpretation ('subjektive Einschätzung') (Held 2001: 117). Similarly, Ulla Kleinberger Günther (2001: 118) claims that a polite speech act can only be effective if the receiver understands how it was intended. Degrees of familiarity and respect between interactants can be described in terms of a "bulge" model: polite behaviour tends to be more attentive and elaborate with acquaintances and casual friends than with people at the two extremes of social distance, i.e. intimates and strangers (Holmes 1995: 13f.). This may be explained by the fact that intimates and strangers are more certain of their relationships and have to work less hard at them, whereas relationships between acquaintances are often insecure and more 'dynamic and open to negotiation' (Holmes 1995: 14, quoting from Nessa Wolfson 1988). 
The linguistic expression of politeness is very often accompanied by para-verbal and nonverbal actions, such as eye-contact, a smile, or a hand-shake. It is impossible in a study of this nature, where the informants are asked open questions about politeness in general and greetings in particular, to separate verbal actions completely from the physical signals that accompany them. For many of my Swiss informants, non-verbal signals were as important as linguistic politeness, and many made fine distinctions regarding such things as the length of eye-contact or of a handshake. Old people, for example, are considered to hold on to their interlocutor's hand for longer than many people consider normal, for example when they want to prevent a visitor from leaving. Another example of politeness given by several people was the behaviour of a person crossing the road at a marked crossing. It seems that pedestrians have only recognized the need to thank drivers who stop at crossings since stopping became required by law some nine years ago. The thanks that are expressed can only be considered a polite speech act in the broadest of terms, because the driver may not be able to hear words spoken by a pedestrian. A mouthed or uttered 'Danke' or 'Merci' is ideally accompanied by a nod, and/or a wave and/or eye-contact. These actions together constitute the act of "thanking".

\section{$1.2 \quad$ Greetings}

As with politeness in general, greetings can be analysed within the framework of theories of "face". When we approach our fellows, we are entering their personal space, their "territory". This can be interpreted as an FTA, particularly if we remain silent, as silence is naturally experienced by human beings as disconcerting: breaking a silence, as in greeting, is a sign of friendly intent ('phatische Verbundenheit', Züger 1998: 29). A greeting, if performed correctly, that is with appropriate words, tone of voice and body language, can attenuate the force of a potential FTA. Many of my informants were aware of the face-saving function of greetings: one greets to show that one wishes to establish a relationship in a non-threatening atmosphere (see section 2.2.i. below). This is also referred to as "phatic communication" (Crystal 1987: 427). "Phatic" refers to a type of communication which signals one's readiness for interpersonal communication and/or one's willingness to interact within a particular community. Katrin Züger documents two aspects of greeting: "Initialphatik" ["initial phatic communication" or "(initial) greeting"] and "Terminalphatik" ["terminal phatic communication" or "leave-taking"]. A greeting exemplifies how a phatic communication act may be "other-oriented" or "self-oriented" (Laver 1975: 223). Self-oriented greetings may include declarative statements, such as 'My legs weren't made for these hills'; other-oriented greetings often contain a question, such a 'How are you?' or comments, such as 'That looks like hard work' (Laver: 223). Holmes believes women to be more other-oriented than men, as exemplified in their greater readiness to accept apologies. She claims that this is because women feel more responsible for social harmony than men; that they are more interested in finding common ground and establishing solidarity (Holmes: 188). In Switzerland, as elsewhere, it is women who tend to perform the very important task of teaching greeting conventions to their children.

Züger stresses the role of "grooming talk" ("Putzsprechen") in the maintenance of social relationships (Züger 1998: 32f.). This is a verbal form of the social grooming performed by 
many species of animal. In humans it accompanies initial greetings, preceding "information talk", and it reappears at the end of an interaction before the leave-taking formulae (Züger 1998: 33). It is particularly important to conduct the leave-taking phase of the interaction efficiently. A cooperative parting serves the function of consolidating the participants' relationships and pre-structuring their next encounter (Laver 1975: 231). A particular subcategory of the act of leave-taking is the reference often made to wider ties of common acquaintance, for example: 'Give my best wishes to Annie', 'Gruss dem Carlo' (Laver 1975: 231). If one is greeting after a long absence, or parting before a long separation, grooming talk is more varied and prolonged. One of my informants always greets each work colleague individually and with a hand-shake on returning from holiday, whereas on a normal day she simply says 'Grüezi mitenand'.

In my research into greeting rituals in GSS it was necessary to differentiate between "passing greetings" and "conversation openings", both of which have a great social importance and specific sets of rules in GSS. A passing greeting is made to both known people and strangers, for example when one passes them in the street, on a mountain path, in the village square, or in shops. Many of my informants stated that it is more important to observe these customs in rural areas than in large towns. Conversation openings, such as telephone calls or social and formal meetings between two or more people, occur between known and unknown interactants and also have their own context-dependent rules.

My informants had their own ideas as to what constitutes a greeting. Like Hauser (Hauser 1998: 17) they recognized a category of "Grüsse an Essende" [greetings to people who are eating]. This, like drinking to one's fellow's health, involves uttering a verbal formula, usually en Guete (mitenand) [bon appetit (everybody)], before starting to eat and drink. A toast requires one of several formulae, for example zum Wohl or Prost. Simultaneously one looks into the eyes of each person present in turn and utters their name. It is polite to wish one's work colleagues en Guete (mitenand) before leaving one's workplace for lunch, and for these colleagues to say merci, gliichfalls [thank you and the same to you]. It is also considered polite to say en Guete to neighbouring customers in a restaurant or a train.

Failure to greet and say goodbye is so remarkable, in rural areas at least, that set phrases exist to describe the feelings of the offended party: me staat da, wie de Hund am Berg/wie e geklepfte Aff [one is left like a dog on a mountain/like an ape that has been clipped round the ear]. Not replying to a greeting is more than impolite; it is seen as a sign of arrogance and animosity. Outsiders who wish to be accepted into Swiss society must learn to greet and take leave properly. One frequently hears complaints that 'die Fremden wissen nicht einmal wie man richtig grüsst' [foreigners do not even know how to greet properly]: the Swiss believe that the least any visitor can do is to learn to greet according to local convention. I can personally vouch for the fact that visitors often find the tasks of phatic communication one of the most difficult aspects of a foreign society: it took me some time to learn that the laxer British greeting customs were inadequate for communication in Switzerland. In her novel Quasi Heimweh, Anna Felder (Felder 1990: 69f.) recounts the experience of an Italian teacher 
whose adaptation to life in German-speaking Switzerland involves learning to greet properly, using the correct formula and the addressee's name:

(...) wir grüßten sie zudem auch so, wie es sich gehört, indem wir sie bei ihrem Namen nannten, der leicht zu behalten war, "Grüezi Frau Wipfe": wir hatten nämlich gelernt, daß wer auf deutsch nur "Guten Tag Frau" sagt, wie wir "buongiorno signora", eine Todsünde begeht, man mußte immer den Namen hinzufügen, und wußte man ihn einmal nicht, dann war es ratsam, laut und lang zu husten, damit auch der komplizierteste Soundso darin noch Platz fand. (Felder 1990: 69f.)

[(...) and we greeted her in the proper way, using her name, which was easy to remember, "Grüezi Frau Wipfe": for we had learnt that in German it was a mortal sin to say merely "Guten Tag Frau", as we would say "buongiorno signora"; one had to include a person's name, and if one did not know it, it was advisable to give a loud, long cough that could conceal even the most complicated appellation.]

\subsection{Motivation for research}

Swiss people adhere to certain conventions of polite behaviour and accompanying linguistic features, such as those of greeting rituals, which have retained much of the traditional complexity that has been lost in the English-speaking world. I started my present research with a number of preconceptions about polite behaviour in GSS as well notions of stereotypes which I had learnt from scholarly literature in the field of sociolinguistics (for example that women are more polite than men, and that most people believe what they perceive as linguistic decline to be the fault of young people). One of my prejudices was that greeting in Switzerland was no more than a social convention and not always conveyed with a true spirit of goodwill. My prejudice was confirmed when I asked a friend about the reasons for the Swiss system of greeting: I was told that greetings were based on 'Nützlichkeit' (self-interest) unless a real 'Zuneigung' (affection) for the addressee were present. Thus when I came to write a questionnaire on politeness and greeting to use in my field-work, this was one of the theses that I set out to test. After questioning 80 informants I found that only one other person thought of greetings as chiefly functioning to bring some (material or non-material) gain to the addressor. From the start of my interviews I became aware that a very large proportion of my informants had a clear idea of the necessity to consider the face needs of their fellow human beings and that a greeting involved entering another person's territory (this important finding will be further discussed below). One thing that I learnt from my first few interviews was that Swiss people genuinely want to oil the wheels of social interaction by adhering to a set of long-standing conventions. They do this not merely to make life easy for themselves, but out of respect, consideration and affection for their fellows.

In his monograph Grüezi und Adieu (Hauser 1998), Albert Hauser documents the changes in greeting rituals since the seventeenth century. He writes of a general degeneration of the "Benimmregeln" (rules of politeness) in twentieth-century Switzerland and the influence of the mass-media (Hauser 1998: 156). According to Hauser, increased demographic mobility and interpersonal familiarity have led to a decline in politeness but a democratization of human relationships (Hauser 1998: 130). Hauser also writes of the decline of "Arbeitsgrüsse' 
(worker's greetings), "Gelegenheitsgrüsse" (greetings for particular occasions or situations) and "Willkommensgrüsse" (welcoming greetings). He describes the complexities of "Zeitgrüsse" (greetings for particular times of day, or of the week or the year) and notes a secularization of greeting rituals. Hauser also provides photographs of seven new types of hand-shake used by young people in Zürich: the Züri-Gruss, the Skater-Gruss, the GimmeFive-Gruss, the Techno-Gruss, the Kiffer-Gruss [pot-smoker's greeting], the Snöber-Gruss [snowboarder's greeting] and the Hip-Hopper-Gruss (Hauser 1998: 165).

My research was designed to investigate further the changes in Swiss greeting culture. I hoped to establish how important the traditional rules of linguistic politeness were for GS Swiss people of all ages and how much change has taken place in recent years. In particular I aimed to assess the effects upon Swiss society of the 'zunehmende Nähekultur' [increasing culture of familiarity] currently experienced in Europe generally (see Held 2001: 127). Does a widespread relaxation of politeness conventions and decrease in formality affect people's feelings of responsibility for the face needs of others? Many of my informants thought that social rules are changing, but none agreed with the prejudice that young people have become more disrespectful (Hinnen 2001: 43). (Hinnen also documents the opposite view: that children have become more open, more approachable and less fearful). I also aimed to test the notion put forward by Holmes that women are more polite than men. Finally, I hoped to investigate the para-linguistic signs of politeness, such as kissing, eye-contact and the shaking of hands: how important are these for the speech acts of greeting and leave-taking as a whole?

\section{$1.4 \quad$ Methods of research}

For practical reasons, I adopted two different methods: one for school pupils and one for adults. In both cases a questionnaire was used to structure the sessions and an open type of question was asked. I interviewed adults individually, writing down the information given to me; the young people filled in their own questionnaires with my help in two classes of some 20 pupils each at the Kaufmännische Handelsschule in Brugg (Aargau). In the case of the younger informants, I had to convince them that I was asking their opinion and not for the "right" answer as in an examination; some of the older informants found a number of my questions obscure, for example the phrase 'soziale Gruppe' frequently had to be explained. Four old ladies of over 90 only agreed to be questioned if they could answer my 'schwierige Fragen' [difficult questions] together. With each interviewee I found that the session went smoothly once I had explained the reasons for my research.

My aim was to conduct a qualitative evaluation of aspects of verbal politeness and greeting in GSS. I found the methods used by Hanna Hinnen for her study of social change in the Graubünden village of Feldis very helpful. Like Hinnen (Hinnen 2001: 209) I used my questionnaire as an aid ("Leitfaden") to get people talking. Hinnen started with a questionnaire of six sides which she in time reduced to two, so I started with three sides and, like Hinnen, was prepared to adjust my questions to suit the informant. I did not push my informants to answer questions which they found difficult. I was nevertheless able to retain a core of questions which were answered by all of my informants, and which I will be able to use to provide a certain amount of quantitative data. 


\subsection{The informants}

My 80 informants were aged between 16 and 96 (43 people under 26 and 37 over 26; 12 of the latter were over 60) and came from a range of social and educational backgrounds: housewives, businessmen, editors of the Schweizerdeutsches Wörterbuch, professors and teachers, two nuns, two hotel owners, a gardener, a foreman, a hairdresser, a dressmaker, a lawyer, two engineers and one opinion pollster. All of these were enthusiastic and helpful, which strengthened my view that a high proportion of GS Swiss people are very interested in their own language and linguistic practices. I must add, however, that I failed to interview anyone who did not believe that politeness and greeting rituals were important (because the few rude people that I met refused to give me an interview).

I questioned people from a variety of regions, from the mountain village of Feldis in Graubünden (4) to the city of Zürich (5). Feldis is a traditiona but all of my informants were native speakers of Swiss German. Most of my informants, and all of the younger informants (those under 26), came from the towns and villages in the canton of Aargau. Of my younger informants, 18 (42\%) were girls and $25(58 \%)$ boys; of the older group (those of 26 and over) $22(60 \%)$ were women and $15(40 \%)$ men.

\section{The results of the survey}

As I had expected, my young informants' answers were generally much briefer than those given by my older interviewees. The young people gave fuller answers than the older group to the questions about actual greeting formulae and much shorter answers to the questions about opinions on various aspects of politeness. Where there are significant differences between the generations I have interpreted their answers separately and provided statistics. Furthermore, I was occasionally able to make generalizations about my 12 informants over 60 . There were fewer group differences between male and female informants, although I have been able to document some specific opinions held by one sex about the other, particularly for the question: Sind Frauen höflicher als Männer? (2.2.iv.). Most of my younger informants wrote all of their answers in dialect; the older group of informants, who were interviewed, spoke either dialect or standard German. Some older informants switched into dialect during the interview and these people generally became more animated after the switch.

The results of my survey fall into two distinct areas, and these will be dealt with in sections 2.1 and 2.2. The first section describes lexical aspects of greeting: the actual formulae that are uttered and the phatic formulae that often follow the initial greeting. The second section documents the opinions and emotions of my informants in relation to greeting rituals: how important is such ritual to most germanophone Swiss? And how well do the traditions of greeting survive in a modern world where formality and convention are said to be in decline?

\subsection{Greeting formulae}

Greeting "properly" in GSS involves more than merely saying grüezi and adieu. Just as with the formal and informal pronouns of address, Sie and $d u$ respectively, levels of formality are strictly observed: thus grüezi (grüess-ech in western regions) is generally accompanied by 
Herr/Frau + family name; salï/sali, hoi, hallo, tschau + first name are informal greetings, and are used more by young people than old. Leave-taking formulae include ade/adieu or uf widerluege for people with whom one is on formal terms, and tschau, tschüss, salü/sali for people with whom one has an informal relationship. Both initial and terminal formulae are often followed by mitenand or zäme (both meaning 'together') if two or more people are greeted. A greeting is generally accompanied by a hand-shake or, when close friends greet, kisses on alternate cheeks (usually three). Leave-taking formulae are frequently accompanied by other pleasantries, such as schöne Tag [have a nice day], schöne Namittag [have a nice afternoon], schönen Aabig/Aabe/Obe [have a nice evening], schöne Fiirtig/Fiiraabig [have a good day/evening off], schöns Wochenend [have a good weekend], schöni Fäschttäg [Happy Christmas], schöni Wienachte/Oschtere [Happy Christmas/Easter], e guets neus Jahr/guete Rutsch [Happy New Year]; en Schöne [have a nice one] is considered uncouth by some people. Such good wishes are generally answered with danke/merci gliichfalls [thank you and the same to you]; indeed many of my informants stressed the importance of this particular formula.

All of my adult informants used a selection of the above formulae and most agreed that it is never enough to just say grüezi to a person one knows: one should always mention the interlocutor's name and it is usually possible to say something topical, even if it is only in recognition of the time of day, as in schöne Namittag. Many informants felt it polite to offer a Gelegenheitsgruss or an Arbeitsgruss if the other person was obviously occupied with a specific task (see section 2.2.xii-xiv below). Otherwise wie gaht's/goht's [how are you], with initial greetings, or schlaf guet [sleep well], with leave-taking, make suitable adjuncts to the basic formulae. One informant told me that in the canton of Wallis it is usual to say gueten Aabe/Obe from 1.00 p.m. onwards. In all other regions the evening begins much later, from about 5.00 p.m. or when the working day has ended.

A steady secularization of greeting formulae, which Hauser attributes to the effects of the Enlightenment (Hauser 1998: 12), is now almost complete. The disappearance of God, as in the degeneration of Gott grüess-di to grüezi and got geb iu guote naht to guete Nacht, was already well under way in the early twentieth century when Anna Zollinger-Escher published her land-mark work on greeting traditions (Zollinger-Escher 1925: 19). 7 of my informants claimed to say bhïet-di Gott [may God keep you] to friends and relatives due to undertake a long journey, but most people were not aware that there had ever been a religious dimension to greeting rituals.

As I suspected that young people use a wider range of greeting formulae than older people, I asked some more specific questions about greeting conventions (questions i.-v. below). I made it clear to the 43 pupils in Brugg that I was looking for both words and actions and was able to gather valuable information about both verbal and para-verbal aspects of greeting. The questions and results follow. Percentages as well as absolute figures are provided for all answers given by $5(12 \%)$ or more pupils. It should be noted that most pupils gave more than one answer: 
i.a. Wie grüssen Sie alte Leute? [How do you greet old people?]

grüezi x 37 (86\%) (plus name x 3); grüezi wohl x 2; guete(n) Tag/Morge/Obe x 13 (30\%) (as an alternative to grüezi); hallo $\mathrm{x} 1$;

one of these formulae plus a smile $\mathrm{x} 4$, a hand-shake $\mathrm{x} 3$, or a nod of the head $\mathrm{x} 3$.

i.b. Wie verabschieden Sie sich? [How do you say 'goodbye'?]

adieu/ade x 37 (86\%); uf widerluege/widerseh x 9 (21\%); schöne Tag/Obelen Schöne x 5 (12\%); tschüss x 1;

- $\quad$ one of these formulae plus a hand-shake $\mathrm{x} 2$.

ii.a. Wie grüssen Sie den Lehrer? [How do you greet your teacher?] grüezi x 41 (95\%) (plus name x 21 (48.5\%)); guete(n) Tag/Morge/Obe x 10 (23\%) (as an alternative to grüezi, plus name $\mathrm{x} 4)$; no greeting $\mathrm{x} 1$.

ii.b. Wie verabschieden Sie sich? [How do you say 'goodbye'?] adieu/ade x 37 (86\%) (plus name x 15 (35\%)); uf widerluege/widerseh x 1; schöne(n) Tag/Obe x 2; no greeting x 2 .

iii.a.Wie grüssen Sie Ihre Eltern? [How do your greet your parents?]

- hallo (zame or Mami/Papi) x 28 (65\%); hoi (zame or Mami/Papi) x 17 (40\%) (as an alternative to hallo); tschau $\mathrm{x} 4$; sali/salü $\mathrm{x} 2$; grüezi $\mathrm{x} 1$;

one of these formulae plus a hand-shake $\mathrm{x} 1$, or three kisses on alternate cheeks $\mathrm{x} 2$.

iii.b.Wie verabschieden Sie sich? [How do you say 'goodbye'?]

- $\quad$ tschüss (zame or Mami/Papi) x 32 (74\%); tschau x 9 (21\%); sali/salü x 1; tschüssli x 1;

- $\quad$ one of these formulae plus bis später x 2, or en Schöne x 3;

- $\quad$ one of these formulae plus three kisses on alternate cheeks $x 4$;

- $\quad$ one of these formulae plus a hand-shake x 1 .

iv.a.Wie grüssen Sie Ihre Kollegen? [How do you greet your friends?]

There were up to 7 alternative formulae per informant;

hoi x 22 (51\%); hallo (as an alternative to hoi) x $18(42 \%)$; tschau x $16(37 \%)$ (as an alternative to hoi and hallo); salü x 9 (21\%); hi x 6 (14\%); moin/moinse x 5 (12\%); hey x 2; Tach x 2; Morge x 1; tschessä x 1; saluti x 1;

one of these formulae plus three kisses on alternate cheeks x 10 (23\%);

one of these formulae plus a hand-shake $\mathrm{x} 2$.

iv.b.Wie verabschieden Sie sich? [How do you say 'goodbye'?]

There were up to 4 alternative formulae per informant;

tschau x 22 (51\%); tschüss $\times 13$ (30\%) (as an alternative to tschau); tschühüss $\mathrm{x} 1$; tschüssli x 1 ; bye $\mathrm{x} 3$; moin $\mathrm{x} 1$; salü $\mathrm{x} 1$; c.u. [see you] x 1 ;

one of these formulae plus (en) Schöne x 10 (23\%); machs guet x 2; bis bald x 2; bis denn $\mathrm{x} 1$; 
- $\quad$ one of these formulae plus three kisses on alternate cheeks x 9 (21\%);

- $\quad$ one of these formulae plus a hand-shake x 1 .

v.a. Wie grüssen Sie Ihre Freundin/Ihren Freund? [How do you great your boyfriend/girlfriend?]

- $\quad$ kisses (usually 3) but no words x $11(26 \%)$;

- a hug and kisses but no words x 5 (12\%);

- $\quad$ hoi x 7 (16\%); hallo x 5 (12\%); sali x 2; tschau x 2; hi x 1;

- $\quad$ one of these formulae plus kisses x $11(26 \%)$;

- one of these formulae plus a pet name (Schatz/Spätzli/Schnägg) [treasure/darling, little sparrow, snail] x 7 (16\%);

one of these formulae plus wie goht's x 2.

v.b. Wie verabschieden Sie sich? [How do you say 'goodbye'?]

- $\quad$ kisses (usually 3) but no words x 12 (28\%);

- a hug and kisses but no words x 5 (12\%);

- $\quad$ tschüss $\times$ 7; tschau $\mathrm{x} 4$; sali $\mathrm{x} 1$;

one of these formulae plus kisses x $8(19 \%)$;

one of these formulae plus a pet name (Schatz/Spätzli/Schnägg) x 3;

one of these formulae plus (en) Schone x 2; or schöne Tag x 1.

Young people also provided a wide range of answers to the questions on greeting using modern methods of communication, such as e-mail and text-messaging. The following questions were also put to older informants:

vi.a.Wie grüssen Sie beim E-mailen? [How do you greet using e-mail?]

vi.b.Wie verabschieden Sie sich? [How do you take your leave?]

$12(32 \%)$ of my older informants use e-mail as a means of communication, mostly at work. Most claimed that an e-mail message is composed rather like a letter, i.e. with few colloquialisms and more formally than an SMS message. For these informants it was important to distinguish between formal and informal relationships between interactants. For people addressed as $d u$ the usual greetings include the name of the addressee plus liebe(r), hallo, hoi or sali/salü. Informal leave-taking formulae include tschüss, es grüsst dich and/or einen schönen Tag. For interactants who address one another as Sie greetings are one of the following as well as the name of the addressee: sehr geehrte(r), liebe(r), hallo, guten Tag. The leave-taking formulae are one or more of the following: tschüss, mit freundlichem Gruss, einen schönen Tag.

My younger informants claimed to write an e-mail in a less formal style than a letter, often using dialect. They knew a wide variety of greeting formulae, each giving a number of alternatives: hoi, hey, hallo, halli-hallo, Grüsschen, moin, hey, tschau, saluti, (guete) Morge or liebe $(r)$ + Name. Formulae for leave-taking were more elaborate still: tschau, tschüss(li), 
sali, hoi, moin, grüessli, greets (presumably under English influence), bye, cu (see you), (Big) Kiss, Küssli, take care, ha di lieb, bis bald, schöne Tag, MFG (mit freundlichem Gruss), LG (liebe Grüsse) and biscus. Only one young person listed possible greeting formulae for use at work: guten Tag and mit freundlichem Gruss.

vii.a.Wie grüssen Sie im SMS? [How do you greet using a text message?]

vii.b.Wie verabschieden Sie sich? [How do you take your leave?]

Only 3 older informants use text messages as a means of communication, whereas only 3 of my younger informants did not. All users agreed that an SMS message is less formal than an e-mail message. In general, e-mail seems to be the preferred modern method of communication in the workplace, while text messages are used by friends. Older informants greeted with hoi, hallo or liebe(r) + Name; they took their leave with tschüss, tschau or Grüsse + Name. One person claimed to use an emoticon (a "smiley") or no greeting at all; another said that he sometimes wrote a text message in dialect.

Young people are the experts at composing text messages. They abbreviate as many words as possible to keep the length of the message to a minimum, indeed a new form of language appears to be emerging in connection with short message systems. Greetings and leavetakings used by youngsters are as varied as those used for e-mails, if not more so. Examples of greetings include hoi, hey, hi, hallo, moin, hey, tschau, (guete) Morge; examples of leavetaking formulae are as follows: tschau, tschüss, sali, hoi, moin, grüessli, bye, cu (see you), (Big) Kiss, Küssli, Schmatz, [a kiss], knutsch (a hug/a kiss), love, take care, mach's guet [all the best], ha di lieb [I love you], bis bald [see you soon], schöne Tag, MFG (mit freundlichem Gruss) [with best wishes], $L G$ (liebe Grüsse) [love from]. Some younger informants use no formulae at all and others use only a "smiley", which is represented with the following symbols: :-).

viii.-X.

The next three questions were intended to ascertain whether people still use traditional, taskoriented greeting formulae as documented by Hauser (1998: 74-78). I chose three occasions where I thought that people might still use special phatic formulae: the first, 'Was sagen Sie einem Menschen, der im Garten arbeitet? [What do you say to a person who is working in his or her garden?], referring to what I thought of as a common activity in many language communities; the second, 'Was sagen Sie einem Menschen, der sein Auto wäscht?' [What do you say to a person who is washing his or her car?], which I thought of as a modern activity that might have replaced a number of more traditional occasions for phatic communication; and the third, 'Was sagen Sie einem Menschen, der im Stall arbeitet?' [What do you say to a person who is working in a cattle shed (or stable)?], which I thought of as a typical traditional situation for phatic communication.

Many informants, both young and old, knew of no formulae for any of these three situations but invented a relevant phrase, such as 'Gut Busch' [good bush!], presumably analogously to 'Gut Schuss' [good shot]. The second question stemmed from a misconception on my part that 
Swiss people wash their own cars, as many of us still do in Great Britain. I was told that most Swiss people take their cars to an automated car-wash, and it was often against local law to wash one's car in the street. This fact did not prevent some informants making appropriate suggestions. I was also told that if a person were working in a cow shed or stable (Stall) one would not see them unless the door were open and in any case most farm-workers were from Yugoslavia. Over 50\% of my informants told me that they would say grüezi on all occasions; the remaining informants made some interesting suggestions, some giving traditional formulae and others inventing something to suit the occasion. It was interesting to note that the informant who is a gardener by profession knew of nothing special to say to people working in their gardens, but knew particular greetings for sportsmen (Hals und Beinbruch), fishermen (Petri heil), sailors (Mast- und Schotbruch) and hunters (Gut Schuss).

viii. Was sagen Sie einem Menschen, der im Garten arbeitet? [What do you say to a person who is working in his or her garden?]

Older informants:

- 4 x 'Wachst's?/Wott's wachse?' [Are your plants growing?]

- 3 x 'Brav!' [Well done!]

- 2 x 'Hallo, ist's heiss/streng ...?' [Hallo, is it hot/hard work?]

- 2 x 'Möchtest du bei mir weitermachen?' [Would you like to come and do mine?]

- 2 x 'Du hast einen schönen Garten/schöne Blumen!' [Your garden/flowers are beautiful]

- 1 x 'Kommt überhaupt etwas?.' [Is anything growing at all?]

- 1 x 'Hoi, kommst du gut vorwärts?' [Hi, how are you getting on?]

- 1 x 'Machen Sie wieder mal alles schön?' [Are you making everything lovely again?]

- 1 x 'Hoi, lieber du als ich!' [Hi, rather you than me!]

Younger informants:

- 4 x 'Schaff ned z'viel!' [Don't work too hard!]

- 2 x 'Sie händ en wonderschöne Garte.' [Your garden is beautiful.]

- 2 x 'Gärtner, guet Busch!' [Gardener, good bushes!]

- 1 x 'Das chönte si bi mer au no mache.' [You could come and do mine too.]

- $1 \mathrm{x}$ 'Wie laufts? Alles schön grüen?' [How's it going? Is everything nice and green?]

- 1 x 'Viel Spass!' [Have fun!]

ix. Was sagen Sie einem Menschen, der sein Auto wäscht? [What do you say to a person who is washing his or her car?]

Older informants:

- 4 x 'Sie können meines auch waschen.' [You can wash mine too.]

- $3 \mathrm{x}$ 'Wird's suuber?' [Are you getting it clean?]

$1 \mathrm{x}$ 'Spinnst du?' [Are you mad?] 
- 1 x 'Brav, brav!' [Well done!]

- 1 x 'Ich kaufe mir immer ein neues, wenn es dreckig wird.' [I always buy a new one when mine's dirty.]

One women suggested that a feasible equivalent to a car would be a person washing windows and claimed: 'Wenn jemand sagt "wird's sauber?", das hab ich nicht gern' [I hate it when someone asks me if I'm getting it clean].

Younger informants:

- 2 x 'Chani mis au härestelle?' [Can I bring mine to you?]

- 2 x 'Wäsch es aber suuber!' [Make sure you get it clean!]

- 2 x 'Putzer, guet Wasch!' [Cleaner, happy washing!]

- 1 x 'Schönes Auto!' [Nice car!]

- $1 \mathrm{x}$ 'Wart doch bis es regnet.' [Wait until it rains.]

- 1 x 'Schöns Usfährtli!' [Have a nice trip!]

x. Was sagen Sie einem Menschen, der im Stall arbeitet? [What do you say to a person who is working in a cattle shed (or stable)?]

Older informants:

- 3 x 'Glück im Stall' [Good fortune in your stable/shed]. This is a traditional formula, documented by Hauser (1998: 78))

- 1 x 'Guet Mischt!' [Good dung!]

- 1 x 'Grüessech, wie läuft's?' [Hallo, how's it going?]

- $1 \mathrm{x}$ 'Anstrengend, nicht?' [Hard work, isn't it?]

- 1 x 'Sind Sie zufrieden mit der Milchleistung?' [Are you satisfied with the milk output?]

- 1 x 'Lieber du als ich!' [Rather you than me!]

- 1 x 'Das würde ich auch gern tun.' [I would like to do that.]

Many of my older informants maintained that they would not expect to meet a farmer at work with his animals; others said that they would think of an appropriate comment depending on what the farmer was doing at the time; still others that only another farmer would know what to say.

Younger informants:

- 2 x 'Buur, guet Heu!' [Farmer, good hay!]

- 1 x 'Schöne Pferde.' [Nice horses.]

- 1 x 'Hallo Bauer.' [Hallo farmer.]

- 1 x 'Puh, wie hältst Du es nur aus hier drin!' [Poo, how can you stand it in here?] 


\subsection{The remaining questions}

i. Warum grüsst man? [Why do people greet one another?]

All of my informants could answer this question and most older people mentioned two or more reasons for the importance of greeting. Two people gave 'Nützlichkeit' (self-interest) as a main answer, but all others were more positive. One category of response that I had most expected to hear, 'man hat das gelernt als Kind' [we learnt it as children] or 'aus Gewohnheit' [out of habit], was only popular with informants over the age of 60 . The two most frequent answers, given by over one third of my informants, were: 'Kontakt herzustellen' [to make contact] and 'Aufrechterhaltung des Kontakts' [to maintain contact]. The second most frequent answer was: 'Aus Höflichkeit' [to be polite], and the third 'um ein Gespräch anzufangen' [to start a conversation]. Other answers demonstrated that many informants have a clear idea of the importance of respect for the "face", both "negative' and "positive", of their interactants: they want to show that they like and respect the other person and that they aim to do so as unintrusively as possible, e.g. 'Als Zeichen, dass man ungefährlich ist' [to show that one is not dangerous], 'zu zeigen, dass man sich kennt' [as a sign of recognition], 'als sozialer Akt' [as a social act] and 'als freundliche Geste' [as a friendly gesture]. Many informants explicitly mentioned respect (Respekt or Würdigung) as a reason to greet. Perhaps surprisingly, only one person gave the response: 'Gäste willkommen zu heissen' [to welcome guests], and only one: 'Wenn man eine Person das erste Mal an einem Tag sieht' [When one sees someone for the first time that day], perhaps because it seemed too obvious an answer for most people to give. One informant might have been speaking for all the others when she said: 'Es ist so normal wie Sand am Meer' [It is as normal as sand at the seaside].

ii. Finden Sie, dass bestimmte soziale Gruppen unhöflich sind? [Do you find particular social groups impolite?]

First I must explain why I asked this rather provocative question. Over the years I have noticed that a variety of outsiders in Switzerland, from punks to drunks and from foreigners to beggars, are criticized either for not knowing how to greet properly or for not greeting at all. As an outsider myself, I know how long it can take to learn the wide variety of conventions of politeness in GSS. I was reassured to ascertain that $51 \%$ of my younger informants (22) and slightly less than $38 \%$ of my adult informants (14) did not believe that any social group were generally impolite: 'Es gibt in allen Gruppen höfliche und unhöfliche' [There are both polite and impolite people in all groups]. Indeed, I spoke with a beggar, representing a social group which is much maligned in many societies, and he wished me 'schönen Aabe' [a nice evening] when I went on my way.

Of the groups mentioned as impolite, foreigners, particularly those from the Balkan states, were the largest group to be condemned: by 17 people $(21 \%)$ of whom 12 were young (15\% of all informants) and 5 old ( $6 \%$ of all informants). Male and female informants of both agegroups had similar opinions. One woman mentioned foreign men as impolite; another woman felt that Moslem women are unable to make eye-contact, if they greet at all, because their 
head-scarves act as a barrier to communication. The second largest group to be criticized (by 5 young people, i.e. 12\%) were Nazis and 'links-/rechtsradikale' [radical left- and right-wing groups]. Other social groups to be mentioned by 1 or 2 informants were punks, drunks, sports fans, people from a low social class, psychologically disturbed people, people under stress, uneducated people, old people, young people up to 17 years old (by a twenty-year-old) and small children under 10 years old (by a 16-year-old).

It was generally recognized that many groups who do not fit into conventional society ("Randgruppen") have their own greeting conventions among themselves: they may not greet according to traditionally accepted convention, but they have special ways of communicating with other social "misfits". There was also some understanding that people from other cultures do not necessarily mean to be rude by Swiss standards when they fail to greet.

iii.a. Sind die Jungen höflich? [Are young people polite?]

iii.b. Auf welche Weise sind sie höflich bzw. unhöflich? [In what way are they polite or impolite?]

All of my informants were able to answer this question, and many gave additional comments including opinions about the comparative politeness of older people (which I will document here). Some informants who asked: 'Was heisst jung?' [what do you mean by young?]. To me, the informants under 26 were young and those over 26 older, but my young informants considered themselves older than children and my informants over the age of 60 considered anyone under 60 to be young. Bearing such subjective judgments in mind it is still possible to draw some general conclusions from the answers to this question.

Of the older group, 18 (49\%) thought that young people were as polite as older people, 12 $(32 \%)$ thought that older people were more polite, and $5(13.5 \%)$ did not know. Of the younger informants, $29(67 \%)$ thought that young people were as polite as older people, 5 (12\%) thought that older people were more polite, and 5 (12\%) did not know.

Traditionally, younger people have been expected to greet older people first and many older people expect this custom to be adhered to (often in vain). Other older people recognize that if young people are to be expected to be polite to them, they must be polite in return, and this might mean greeting first. My 4 female informants over the age of 90 agreed that they had more time than younger people to pay attention to the conventions of politeness. They also agreed that most young people are very polite, even saying 'danke' when old people stand aside to allow them to pass on their skateboards.

Both negative and positive judgements were expressed by both old and young informants about the old and the young generally. Young people claimed that older people were 'freundlicher' [more friendly] and 'geduldiger' [more patient]; on the other hand they can be 'mürrisch' [surly] and 'stur' [stubborn]. Young people were often seen as 'höflicher' [more polite], 'offener' [more open], 'lebenslustiger' [fuller of the joy of living], 'kontaktfreudiger' [more sociable], and more likely to smile when greeting one another. My older informants may see themselves as 'anständiger' [better behaved] and more genuinely interested in their speech partner, but also as likely to be 'gehemmter' [more inhibited] and 'stur' [stubborn]. 
Informants of all ages agreed that old people are 'grussfreudiger' ('sie grüssen eher' [they greet more readily]). No older people claimed that young people are impolite, but one woman claimed that older people speak more precisely than young people - a perception which is common to many cultures. Finally, one of the nuns that I questioned commented that young people have been calling her 'Pinguin' [penguin] and 'ferngesteuerter Kohlensack' [remotecontrolled sack of coal] for decades.

iv.a. Sind Frauen höflicher als Männer? [Are women more polite than men?]

iv.b. Wenn ja, auf welcher Weise? [If they are, in what way?]

According to Janet Holmes, women are more positively polite than men. They take responsibility for social cohesion, are more cooperative than men in many communicative situations, and avoid FTAs more resolutely than men. Their politeness may be seen as resulting from their powerlessness in society (Holmes 1995: 19), or it may be a consequence of their being more sympathetic and attentive to others ("other-oriented") than men (Holmes 1995: 7). Holmes drew her conclusions from a large number of studies on gender and politeness. My aim with Question iv was to see if they could be confirmed with respect to politeness in GSS.

Many of my younger informants were surprised that such a question should be asked and most (11 (61\%) girls and $21(84 \%)$ boys) answered 'No'. One older (male) informant said that I was asking about an "antiquated" stereotype, but he was still able to give me examples of women being ruder than men. Of the older group, 6 women and 7 men thought that women were politer than men; 9 (41\%) women and 6 (40\%) men thought the opposite; and $3(14 \%)$ women and $2(13 \%)$ men did not know.

Most of the additional comments originated with female informants and supported Holmes's finding that women are more other-oriented than men. Girls found that women are 'herzlicher' [warmer], 'verständnisvoller' [more understanding] and 'weniger primitiv' [less crude]. One girl wrote: 'Sie haben von Natur aus eine freundliche Ausstrahlung' [they have a naturally friendly way about them]. Boys commented that women are more polite on the telephone but that their politeness is often somewhat exaggerated ('etwas übertrieben'). Older female informants considered women 'rücksichtsvoller' [more considerate], 'aufmerksamer' [more attentive], 'herzlicher' [warmer], 'achtsamer' [more courteous and thoughtful], 'hilfsbereiter' [more helpful], 'respektvoller' [more respectful], 'offener' [more open], 'spontaner' [more spontaneous]; they are also seen as better listeners and as less obsequious than they once were ('weniger unterwürfig wie früher'). One man also mentioned that women are more open and talk more readily about their problems. As far as the other male informants were concerned, few additional comments were made. One man claimed that women still frequently wait for the man to greet first, as was formerly dictated by tradition; another had noticed that women give more details than men when answering questions: this informant's job involved conducting opinion surveys, and he had noticed that women usually give precise reasons when refusing to be questioned, unlike men, who usually just say 'No'. 
There were few claims on the part of one sex that members of the other were actually rude. One woman said that men are more polite towards men than towards women, and one claimed that foreign men are rude to Swiss women (see 2.2.ii. above). Another woman portrayed men as 'zielgerichteter höflich' [more purposefully polite]. One man felt that women are often rude when they are trying to show that they are emancipated.

Some differences in para-linguistic behaviour were mentioned, especially that women kiss women and men, while men kiss only women and shake hands with men; also that young girls have recently started to kiss other girls on the mouth rather than on alternate cheeks.

v. Kennen Sie ein Sprichwort über das Grüssen, wie z.B. "Höfli si und gueti Wort ge, bricht keinem sMuul"? (Hauser 1998: 52) [Do you know a saying about greeting, for example "Being polite and saying a kind word can't break your mouth"?]

I was not surprised that only $12(32 \%)$ older people and $6(14 \%)$ younger people knew a saying about greeting. 2 young people misunderstood the purpose of the question and simply answered 'Yes'. The answers are as follows:

Older informants:

- 3 x "Wie man in den Wald hineinruft, so kommt es wieder heraus!". A literal translation of this saying would be something like: 'What you call into the forest comes back sounding just the same', i.e. 'Expect others to treat you as you treat them'.

- 3 x "Höflich sein kostet nichts!" [Politeness costs nothing!]

- 2 x "Wänn dis Muul Sonntig hät, hät miis Fiirtig!" [If it is Sunday for your mouth, then it's a day off for mine!] I was informed that this saying comes from the St. Gallen Rheintal.

- 2 x "Mit dem Hute in der Hand, kommst du gut durch das ganze Land." [With your hat in your hand you can travel throughout the land.]

- 1 x "Grüss Gott tritt ein, bringt Glück herein." ["Grüss Gott" enters and with it comes happiness.]

1 x "Grüss Gott, heb Gott vor Auge." ["Grüss Gott", keep God in your sight.]

Younger informants:

- $\quad 2$ x "Wie man in den Wald ruft, so kommts auch zurück." (see translation above)

- $1 \mathrm{x}$ "Wie man einem Menschen entgegenkommt, so kommts zurück." [Expect others to treat you as you treat them.] This is basically the same saying as the one above.

- $1 \mathrm{x}$ "Es Lache chostet nüt." [A smile costs nothing.]

- 1 x "Am Morge früe es liebs Wort erfroit s'Härz de ganz Tag." [A friendly word in the morning gladdens the heart the whole day long.]

- $\quad 1$ x "Me muess ja noch grüesse!" [(But) one must greet one another!]

- 2 x "Ja." 
vi. Von wem lernen Kinder die Höflichkeitsformen? [From whom do children learn greeting conventions?]

Every informant answered this question and all but one had been taught as a child that to greet properly was the first rule of politeness: 'Gib schön die Hand' [give your hand nicely] and 'Sag schön grüezi' [say hallo nicely] are phrases known to most children in GSS. Many older people, but no informants under 26, also mentioned school as a place where one may be taught the basics of polite behaviour. Several older people lamented that politeness was no longer taught in schools and that many modern parents neglected their duties in this respect. One nun, who had also trained as a nurse, had received classes in etiquette during her training. The one informant who had not learnt good manners from his parents or his school had been taught by his grandmother.

vii. Grüssen Sie immer, auch wenn es Ihnen nicht gut geht? [Do you always greet, even when you are not feeling too good (i.e. ill or ill-humoured)?]

The majority of my informants claimed to greet invariably, whatever they felt like. Of the younger informants, 24 (56\%) gave a clear 'Yes' as an answer, 9 (21\%) (all girls) said that they usually greeted, and 8 (19\%) (5 boys and 3 girls) admitted to not greeting if they were not feeling friendly or cheerful. Of my older informants, 3 men and 2 women (13.5\% of older informants) claimed not to greet if they were feeling bad; the remainder of my informants claimed to greet however they felt. Several people said that they greeted strangers more readily when they were happy, and more in summer than in winter

viii. Kann man unhöflich grüssen? [Can one greet impolitely?]

Inspired by an informant, I thought of this question only half-way though my interviews and therefore only put it to $19(51 \%)$ older informants. Greeting impolitely is a serious FTA and similar, if not worse, in severity to not greeting at all. There are various reasons why a person might greet impolitely: people from foreign cultures may not know the Swiss greeting conventions, and Swiss people may or may not intend to be rude. If a person wishes to show dislike of another person, greeting in a rude or off-hand manner is a good way of doing it. According to my informants, however, most GS Swiss people do their best to disguise their antipathy towards others.

$13(68 \%)$ of the 19 older people believed it possible to greet impolitely, 4 did not and 2 claimed that they would not greet at all if they intended to be rude. The commonest way of greeting in an unfriendly fashion is to adjust one's tone of voice and to limit one's words to the essential minimum, for example a surly Morge rather than Guete Morge. Wie gaht's?. Other ways are adjusting one's facial expression, not offering one's hand, not uttering the addressee's name, and avoiding eye-contact ('das ist schlimmer als nicht grüssen' [that is worse than not greeting at all]). All of these methods complement the curtailed verbal greeting to create a highly disrespectful speech act. 
ix. Wie grüssen Sie einen Menschen, den Sie nicht mögen? [How do you greet a person whom you do not like?]

All of my informants claimed to greet people differently, depending on how much they liked them. A significant difference between younger and older informants was that $14(32.5 \%)$ of the under-26 group but only 2 of the over- 26 group did not greet people at all that they did not like. For the older informants, grüezi was the commonest unenthusiastic greeting formula $(8=$ $22 \%)$; for the younger people, hoi or hallo were equally popular $(19=44 \%)$ and were given as alternatives by most, followed in popularity by grüezi $(10=23 \%)$. The more friendly salü/sali was suggested only by one young informant. The manner of greeting was as important as the formula, brevity being the most popular mode, e.g. Morge or Tag not preceded by the more usual guete. The use of a less friendly tone of voice, the absence of a smile and/or eye-contact and the failure to address the interactant by name were also considered important. In many cultures it is normal to be more polite to people that one does not like, but only 7 (19\%) older informants claimed to greet people whom they disliked politely. One informant hoped that people he did not like did not notice this from the way he greeted them. Most of my informants responded to this question very fully, offering up to 6 combinations of answers, e.g. 'knapp' [briefly, abruptly], 'kalt' [coldly], 'neutral' [neutrally, disinterestedly], 'nicht unhöflich' [not impolitely], 'korrekt' [correctly], 'ohne Lächeln' [without a smile].

x. Wie grüssen Sie einen Menschen, den Sie gut mögen? [How do you greet a person whom you like?]

The chief differences between greetings addressed to people one does and does not like are in the length of the greeting and in the degree of formality. Greetings to people who are liked are frequently followed by a "Gelegenheitsformel", such as 'wächst's?' [are your plants growing?] (see questions 2.1.viii.-x. above) or by phatic formulae, such as 'schönes Wetter heute' [nice weather today] or 'wie geht's?' [how are you?]. A mention of the addressee's name is important, as are kisses, smiles, hugs, waves, hand-shakes, a friendly tone of voice and eyecontact. Younger people preferred the formulae hoi, hallo, moin, tschau and tschüss, also the endearments Schatz [treasure, darling] and Spatz [sparrow, darling]; older informants found hoi and hallo friendlier than grüezi.

One informant told me that she greets people she likes very much with the informal Morge (as opposed to guete Morge). As stated above (2.2.ix.), this formula is also used to greet people who are not liked. The abbreviated greeting is polite when addressed to one social extreme (intimates and allies) and impolite when addressed to the other (strangers and antagonists); those with whom one's relationship is less assured, i.e. acquaintances and casual friends, are more likely to be addressed with the full formula, guete Morge (this could be seen as a variant of the "bulge" effect described above and by Janet Holmes (1995: 13f.)). 
xi. Wie verabschieden Sie sich von einem Verwandten oder einem guten Kollegen, der eine lange Reise antritt? [How do you take your leave of a relative or good friend who is about to leave on a long journey?]

Taking leave before a long absence is a speech act which is very likely to be accompanied by "grooming talk" as described above (section 1.1). Verbal grooming is likely to be more thorough if a long absence is anticipated. The answers to this question were very similar to those to the previous question. For both young and old, gueti/schöni Reis [have a good journey] is the commonest supplement (for 21 (26\%) informants), gueti/schöni Ziit [have a good time] was suggested by $4(9 \%)$ young informants, and mach's guet [all the best] by 5 (13.5\%) older and $19(44 \%)$ young people. Most informants mentioned between 2 and 6 combinations of formulae, which included verbal and non-verbal features, e.g. tschüss, mach's guet, schöni Ziit and alles Gueti as well as 3 kisses. Other supplements ("Ergänzungen") included: chomm guet an [get there safely], chomm heil retour [come back safely], pass uf di uf [take care of yourself], heb dir Sorg [look after yourself], leb wohl [farewell], en Schöne [have a good one], viel Spass [have fun], Hals- und Bei(n)bruch [break a leg], mäldschdi/mäldsch-di wenn $d$ zrück bisch [keep in touch/get in touch when you get home]. Only 3 older informants plus my 4 ladies over 90 mentioned bhüet-di Gott [may God keep you] as a common supplement. Physical gestures play an important role in leave-taking and a wider variety were mentioned by my informants than for any other occasion. As well as kisses ('3 Küssli'), hugs, and hand-shakes, one person suggested that she would take both hands of the person who was departing and one man said that he would touch a colleague on the shoulder.

xii. Wie fühlen Sie sich, wenn Ihr Gruss nicht erwidert wird? [How do you feel when your greeting is ignored?]

Failure to respond to a greeting is a very serious FTA. How a person feels when his or her greeting is ignored depends upon the reasons for this omission. The commonest and most excusable reason for a failure to reply is a simple failure to see or hear the other person. Many of my informants said that if they suspected this to be the case they would greet again, loudly. If a failure to greet is due to ill will, the positive face of the victim can be severely damaged: people can worry for days if a friend or acquaintance does not greet them. 5 (13.5\%) of my older informants admitted to worrying deeply about the reason for their having been ignored; only 2 people (one young, one old) said: 'Dann grüss ich nie wieder' [I never greet that person again]. Only $6(16 \%)$ older informants and $5(12 \%)$ younger informants claimed not to mind if their greetings were not returned. The remainder of the older informants minded very much. A wide variety of adjectives was suggested to describe how both young and old feel when their greeting is not answered: 'beleidigt' [offended], 'hässig' [angry], 'wütend' [furious], 'gekränkt' [hurt], 'scheisse' [shitty], 'irritiert' [irritated], 'frustriert' [frustrated], 'sauer' [annoyed], 'enttäuscht' [disappointed], 'zurückgestossen' [rejected], 'perplex' [perplexed], 'blöde' [stupid] and 'verachtet' [despised]; 'Ich denke, blas mir in die Schuhe' [in the sense of 'blow you, see if I care']. A number of pejorative epithets were suggested: Arschloch, Idiot, blöder Flegel, Dobbel. Only one younger person thought that failure to greet was not a 
serious offence and said that thousands of people do not greet nowadays. Another young informant thought that anyone who does not greet must be a very unhappy person.

xiii. Glauben Sie an einen allgemeinen Verfall der Sitten? [Do you believe that there has been a general decline in manners?]

Most of my informants were able to answer this question: 38 (47.5\%) with a clear 'Yes', and $20(25 \%)$ with a clear 'No'. Interestingly, 19 (44\%) young people answered 'Yes'. 5 (12\%) young people and $5(13.5 \%)$ older people claimed that there has been a change (Wandel) rather than a decline. In particular, modern developments in communication technology, such as e-mail, were considered responsible for a departure from traditional linguistic conventions. 2 people over the age of 60 made it clear that change is not necessarily a bad thing. If anyone was blamed for a decline in manners it was parents, but several informants believed that parents still do a good job: 'Die Eltern schauen schon auf die Höflichkeit der Kinder' [parents make sure that their children are polite]. One informant blamed any decline in manners on the "hippy generation", whose anti-authoritarian beliefs have caused them to neglect teaching their children how to live in the community.

A particularly common answer, especially from my informants over 60, related current greeting practices to the speed of life in the modern world: people, particularly young people, were seen as always being in a hurry, although not all old people condemned them for this. One elderly woman claimed that the increased use of cars prevents people from greeting one another, and that people are not generally as friendly as they used to be: it is important to continue teaching children to greet 'um die Sitte aufrecht zu erhalten' [to preserve tradition].

My informants in the older group made more additional comments than those in the younger group. It was interesting to note, however, that my younger informants saw themselves as older people and commented that children are not taught manners: 'Kinder grüssen nicht mehr auf der Strasse' [children no longer greet in the street]; one wrote 'Es ist nicht mehr das Gleiche wie früher' [things are not like they used to be]! A number of older informants found that greeting conventions are becoming simpler and less individual; greetings with "content" and a mention of God are being replaced by a brief grüezi or adieu.

xiv. Haben Sie weitere Bemerkungen? [Do you have any further comments?]

Informants over 26:

Nearly every older informant had two or more answers to this question. Several of my informants drew my attention to the basic need to greet ('man hat den Bedarf zu grüssen'): only a few Eigenbrötler [loners] are held not to greet. Some people complained of a dehumanization of modern society; others were certain that greeting rituals were much as they always had been and appreciated by most people. One informant told of the training in politeness given by certain public service companies to their employees: in her opinion the employees of the postal service are well trained, those of the State Railway badly trained. 
Many people from both urban and rural areas stressed the differences in greeting habits between people from the different environments: many town-dwellers claimed: 'Auf dem Land grüsst man mehr als in der Stadt' [People who live in the country greet more than those who live in towns], and village-dwellers said: 'In der Stadt wird nicht gegrüsst' [People in towns don't greet one another]. In fact, the rural/urban difference is chiefly a matter of whether or not one greets strangers: wherever one is it is normal to greet a person one knows, but in rural areas of Switzerland, as in Britain and many other countries, one is more likely to greet strangers if one encounters them on a country walk or in a small village. Hanna Hinnen points out another fundamental feature of greeting conventions in rural areas: inter-family feuds in small villages are more acute than in towns, and they can often continue for years. In her study of the village of Feldis in Graubünden, Hinnen reports on families who have not greeted one another for ten years or more. She tells of one child who would be told at the meal table whom she was allowed to greet and whom she should ignore: 'Mein Vater sagte jeweils am Tisch, wen man grüssen durfte und wen nicht. Manchmal durfte man dann einen plötzlich nicht mehr grüssen. Das gab so ein Sippengefühl, das durfte nicht gebrochen werden' [My father would tell us at meal times whom we were allowed to greet and whom not. Sometimes we were suddenly told not to greet a person. There were family bonds that one was not allowed to break]. (Hinnen 2001: 173).

Comparisons were made with other countries. America is seen as a land where people ask after a person's wellbeing without necessarily being interested in the answer: in Switzerland, apparently, people really want to know the answer when they ask: 'Wie geht es Dir?' [How are you?]. Italians were recognized by two informants as more open and genuine than the Swiss. Finally, as one nun remarked, God is disappearing from greeting formulae in Switzerland but not in Germany: 'In Deutschland sagt man noch Grüss Gott' [in Germany they still say Grüss Gott].

Regional differences within Switzerland were also remarked upon. Two people claimed that the Welsche (the French-speaking Swiss) greet more warmly and are generally more open and friendly than their germanophone compatriots. Inhabitants of the canton of Appenzell were seen by one informant as 'grussfreudiger' [keener to greet people] than others. The canton of Appenzell has for centuries had the reputation both of greeting in a friendly manner and addressing more people with the informal pronoun $d u$ (see also Hauser 1998: 112 and 116). One elderly informant told me that during her childhood in Appenzell it was customary to say 'Grüezi' on meeting a person in the street and 'Adieu' as one walked on. Greetings in Bern, on the other hand, were classed by another informant as 'förmlicher' [more formally].

Comments were also made on the para-verbal aspects of greeting, for example that there has been a recent increase in the number of kisses given from two to three and that the third kiss was imported from French-speaking Switzerland. One informant felt that three kisses is one two many ('zweimal genügt' [two are sufficient]); another liked to see young people kiss as well as shake hands. 
Informants under 26:

Not all of my young informants answered this question. Three main types of answer are recorded which are broadly similar to some of those given by older people: that one should treat others as one would wish to be treated oneself; that the Swiss are naturally friendly and polite; and, conversely, that Swiss people are becoming less outgoing and "human". The only other answers were light-hearted: 'Ein Lächeln schadet nie' and ':-)' (a "smiley").

$\mathrm{xv}$. The unasked question: What is considered to be polite and impolite linguistic behaviour?

Perhaps wrongly, I omitted to ask my informants what they thought of as linguistic politeness and impoliteness. A number of my adult interviewees gave me their opinions anyway, or rather told me what they thought of as particularly rude. One man, for example, associated failure to greet with the type of woman who removes her shoes in trains and puts her feet on the opposite seat. Men, presumably, do not commit this offence. A common complaint was that making a telephone inquiry is becoming increasingly impersonal; that firms use recorded messages and a system of numbers to be dialled rather than providing a human being as the first contact with customers. There were also complaints about the amount of time one is left listening to music in such circumstances. A similar situation pertains in banks, where customers are increasingly expected to use cash machines rather than deal with a teller at a counter. The "next customer" (Nächster Kunde) dividers in supermarkets were a matter of concern for one man: they spare people from having to communicate verbally about which items of shopping belong to which customer. The same informant complained about a "lower" class of person who has recently started to use $i h r$ (the second person plural pronoun) as a polite form of address in the canton of Aargau: ihr is an acceptable polite form of address in the canton of Bern and in some other western GS areas, but it is not a traditional feature of other dialects. Finally, a person who moves too close to another during a communicative act is seen as intimidating: several of my informants described a situation which sociolinguists call an FTA - in this case a threat to a person's negative face.

\section{Conclusion}

My interviews showed me that greeting is the minimum token of politeness that most germanophone Swiss expect to give and receive at the beginning and end of a communicative act: greeting rituals are the heart of good manners and civilized behaviour for men and women, young and old. For many people, physical gestures and eye-contact are as meaningful as the words of greeting formulae. It seems safe to say that most GS Swiss have a keen awareness of both the positive and negative face needs of others and that they aim to preserve their fellows' positive opinion of themselves and to avoid invading their personal space. All of my 80 informants were sensitive to FTAs, which, if they are the victim of one, can play on their minds for a considerable amount of time.

Each of my informants believed that greeting rituals are a vital aspect of human communication. Only one woman said she would prefer not to have to greet everyone she met; 67 (84\%) greet everyone they know, even when they feel ill or uninclined to be sociable. 
$69(86 \%)$ people claimed to feel slighted if their greeting is not answered; 13 () out of 19 $(68 \%)$ older informants said that it was possible to greet impolitely, for example if they did not like a person, and they would greet rudely rather then not at all. All of my informants showed enthusiasm for my survey, in fact it was occasionally difficult to draw an interview to a close. With old people in particular a conversation about politeness led to a more general discussion about interpersonal relationships and the structure of Swiss society.

It was outside the scope of my survey to undertake a full investigation into regional differences in greeting rituals, but many of my informants believed that the basic difference in greeting conventions between rural and urban areas, namely that country folk greet more readily than town people, was more salient than any other geographical difference. As far as social variables were concerned, generation was a decisive factor, gender less so, although many women's answers were fuller and more differentiated, if less certain and assertive (they answered 'Ich weiss nicht' [I don't know] more than men).

Most of my informants were optimistic about the continuing good health of traditional greeting practices: a degree of modern simplification in formulae was recognized, but a total degeneration of greeting habits is not in sight. Only two pessimists, both over 26, believed that greeting was in many cases a self-serving speech act and that the Swiss are getting generally more self-oriented, but they agreed with my other informants that greeting is basically a positive act. The words of one young person represent the feelings of many: 'Ich denke, hier in der Schweiz ist es normal, das man freundlich zueinander ist. Ich finde es schön' [I think that it is normal here in Switzerland for people to be friendly. I think it is great].

\section{Bibliography}

Brown, Penelope/Levinson, Stephen C. (1987): Politeness. Some universals in language usage. Cambridge.

Crystal, David (1987): The Cambridge Encyclopedia of Language. Cambridge.

Felder, Anna ([1970]/1990): Quasi Heimweh. Roman. Frankfurt am Main.

Hammer, Françoise (2001): "Höflichkeitsstile in Anrufbeantwortertexten". In: Lüger, HeinzHelmut (ed.): Höflichkeitsstile. Frankfurt a.M./Berlin/Bern etc.: 129-146. (= Cross Cultural Communication 7).

Hartung, Martin (2001): "Höflichkeit und das Kommunikationsverhalten Jugendlicher". In: Lüger, Heinz-Helmut (ed.): Höflichkeitsstile. Frankfurt a.M./Berlin/Bern etc.: 213-232. (= Cross Cultural Communication 7).

Hauser, Albert (1998): Grüezi und Adieu. Zürich.

Held, Gudrun (2001): "Richtig kritisieren - eine Frage des höflichen Stils? Überlegungen anhand italienischer, französischer und österreichischer Beispiele". In: Lüger, HeinzHelmut (ed.): Höflichkeitsstile. Frankfurt a.M./Berlin/Bern etc.: 113-128. (= Cross Cultural Communication 7).

Hinnen, Hanna (2001): Feldis/Veulden. 100 Jahre sanfte Entwicklung? Regensberg/ Zürich. Holmes, Janet (1995): Women, Men and Politeness. London/New York. 
Kleinberger Günther, Ulla (2001): "Sprachliche Höflichkeit in innerbetrieblichen $e$-mails". In: Lüger, Heinz-Helmut (ed.): Höflichkeitsstile. Frankfurt a.M./ Berlin/Bern etc.: 147-164. (= Cross Cultural Communication 7).

Laver, John (1975): "Communicative Functions of Phatic Communion". In: Kendon, Adam/ Harris,Richard M./Key, Mary Ritchie (eds.): Organiation of Behavior in Face-to-Face Interaction. The Hague/Paris: 215-238.

Lüger, Heinz-Helmut (2001): "Höflichkeit und Höflichkeitsstile". In: Lüger, Heinz-Helmut (ed.): Höflichkeitsstile. Frankfurt a.M./Berlin/Bern etc.: 3-23. (= Cross Cultural Communication 7).

Rash, Felicity (1993): "Gwaggli and Gwagglitante. The use of epithets for men and women in Swiss German past and present." In: Flood, John L./Salmon, Paul/Sayce, Olive/Wells, Christopher (eds.): Das unsichtbare Band der Sprache. Studies in German Language and Linguistic History in Memory of Leslie Sieffert. Stuttgart: 597-626.

Rash, Felicity (1998): The German Language in Switzerland. Multilingualism, Diglossia, and Variation. Bern. (= German Linguistic and Cultural Studies 3).

Rash, Felicity (2000): "Language-use as a theme in German-language Swiss literature." Language and Literature 9: 317-341.

Werlen, Iwar (1992): '... mit denen reden wir nicht'. Schweigen und Reden im Quartier. Basel.

Zollinger-Escher, Anna (1925): Die Grussformeln der deutschen Schweiz. Freiburg i.B.

Züger, Katrin (1998): Säg öppis! - Phatische Sprachverwendung. Eine linguistische Untersuchung anhand von schweizerdeutschen Gesprächen in öffentlichen Verkehrsmitteln. Bern. (= Zürcher Germanistische Studien 51). 